\title{
Creating Shared Value Through an Inclusive Development Lens: A Case Study of a CSV Strategy in Ghana's Cocoa Sector
}

\author{
David Ollivier de Leth ${ }^{1} \cdot$ Mirjam A. F. Ros-Tonen²
}

Received: 2 February 2019 / Accepted: 26 March 2021 / Published online: 21 April 2021

(c) The Author(s) 2021

\begin{abstract}
Despite the widespread popularity of the Creating Shared Value (CSV) discourse, its 'business case' and 'win-win' rhetoric remain problematic. This paper adds an inclusive development perspective to the debate, arguing that analysing CSV strategies through an inclusivity lens contributes to a better operationalisation of societal value; makes tensions and contradictions between economic and societal value explicit and uncovers processes of inclusion, exclusion and adverse inclusion. We illustrate this by analysing Nestlé's CSV strategy in its cocoa supply chains in Ghana based on content analysis of company documents, interviews with value chain actors and stakeholders, and focus groups with farmers. We ask how Nestlé frames and implements its CSV discourse in practice and how this relates to the social, relational and environmental dimensions of inclusive development. Findings show how the company addresses inclusive development dimensions in its corporate discourse, practices and business operations, and what trade-offs it faces. We then unmask the inherent tension between business objectives and societal interests and explain why the scope, issues addressed and societal impacts of CSV remain constrained. We conclude that CSV can help reduce a company's impact on some persistent societal issues, but that its contribution to transformational change remains limited because the need to uphold competitive advantages and short-term financial performance narrows its ability to address all inclusivity dimensions. Legislation mandating responsible business conduct and due diligence can reduce this inherent tension by levelling the playing field between companies addressing inclusivity issues vis-à-vis those who do not.
\end{abstract}

Keywords Creating shared value $\cdot$ Inclusivity $\cdot$ Inclusive development $\cdot$ Cocoa $\cdot$ Ghana $\cdot$ Nestlé

\section{Introduction}

Michael Porter and Mark Kramer's (2011) article on Creating Shared Value (CSV) has shaped what is currently one of the most influential views on how businesses should operate in society. This approach asserts that businesses should overcome perceived trade-offs between their own corporate objectives (e.g. profitability, competitiveness) and societal interests (e.g. positive social or environmental outcomes)

Mirjam A. F. Ros-Tonen

m.a.f.ros-tonen@uva.nl

David Ollivier de Leth

d.ollivierdeleth@gmail.com

1 International Development Studies, University of Amsterdam, Amsterdam, The Netherlands

2 Department of Geography, Planning and International Development Studies, University of Amsterdam, Nieuwe Achtergracht 166, 1018 VW Amsterdam, The Netherlands by focusing their corporate strategies on shared value creation. The CSV discourse assumes that incorporating externalities (such as pollution) into companies' business models will positively affect their long-term profitability (Porter \& Kramer, 2011). Rather than targeting the redistribution of 'existing value' in value chains, CSV aims at generating greater (economic) value and benefits for all stakeholders in a production process ('increasing the size of the pie') by reconceiving products and markets, redefining productivity in the value chain, and enabling local cluster development. According to Porter and Kramer (2011, p. 17), CSV is therefore a logical consequence of 'a deeper understanding of competition and economic value creation'. Porter and Kramer (2011) consider this to be a key difference with the Corporate Social Responsibility (CSR) approach, which they see as being driven by reputational or philanthropic considerations, focused on 'doing good', and external to the core operations of the business. The CSV approach has found strong resonance among multinational enterprises, including 
Novartis, Walmart, Nestlé and Coca-Cola (Dembek et al. 2016). This paper focuses on Nestlé's CSV strategy, which Porter and Kramer have used frequently to support their argument. ${ }^{1}$

To Porter and Kramer (2011), CSV represents nothing less than 'a reinvention of capitalism'. Critics have however argued that the CSV approach is unoriginal, too companyand Western centric, and naïve about the way in which businesses operate in society (Beschorner, 2013; Crane et al. 2014; Dembek et al. 2016; Voltan et al. 2017). They also argue that the CSV approach fails to address structural issues by solely focusing on the behaviour of individual companies and as such extends capitalism to new frontiers by proposing the commodification of environmental resources or simply regarding poverty as a new opportunity for profit and accumulation (Blowfield \& Dolan, 2014; Voltan et al. 2017). Critics furthermore point to the fact that claims of compliance with legal and ethical standards do not hold in practice, seeing that even 'frontrunner companies' are often still linked to cases of human rights abuse or environmental damage (Crane et al. 2014).

The criticism taken up in this paper concerns the conceptual vagueness and poor operationalisation of 'shared value' (Dembek et al. 2016); the failure to recognise the inevitable trade-offs between business and societal interests (Crane et al. 2014; De los Reyes, 2017); and the weak, at best anecdotal empirical basis of the CSV approach, particularly in the global South (Aakhus \& Bzdak, 2012; Crane et al. 2014; Dembek et al. 2016; Schmitt \& Renken, 2014; Voltan et al. 2017). In light of these critiques, this study aims to theoretically deconstruct the CSV approach by applying an inclusive development lens from the field of international development studies (Gupta \& Vegelin, 2016; Gupta et al. 2015; Hickey et al. 2015; Pouw \& Gupta, 2017). Inclusive development theory helps to operationalise societal value and makes the inherent tension between business objectives and societal value more transparent, thus challenging the often taken-forgranted assumption that economic and societal goals can and will be combined easily in companies' strategies.

By analysing the CSV discourse and practices of Nestlé in its cocoa value chains originating in Ghana, this study contributes to the still limited body of research on how corporations interpret, define and apply CSV (Blowfield \& Dolan, 2014; Corazza et al. 2017); how other value chain and beyond-the-chain actors regard CSV initiatives

\footnotetext{
1 The close link between the 'architects' of the CSV discourse and Nestle is not only evidenced by the fact that Nestlé is a much-cited example in Porter and Kramer (2011) and in Porter et al. (2015), but also by Michael Porter being a member of Nestlé's CSV Advisory Board (Lenssen and Lenssen, 2019; Nichols 2011) and Nestlé's support of a study on its CSV strategy in India, for which Porter and Kramer wrote the foreword (Biswas et al. 2014).
}

and partnerships (Banks et al. 2016); and how companies address tensions and trade-offs regarding the outcomes of shared value creation processes that may also reach beyond the direct value chain (Dembek et al. 2016; T. Hahn et al. 2010). It thus feeds the broader academic and societal debates on CSV and the role of companies as development actors (Banks et al. 2016; Blowfield \& Dolan, 2014; Scheyvens et al. 2016; Sharp, 2006). We thereby aim to avoid dogmatisms that simply view businesses as 'good' or 'bad' (Christensen, 2007).

After introducing the conceptual framework, this paper outlines the methodology of the research and introduces the cocoa value chain, Ghana's cocoa sector, and the most important value chain inclusivity issues. It then presents the outcomes of the analysis of Nestlé's CSV strategy in its cocoa supply chain in Ghana. The article closes by situating the main findings in the broader literature on trade-offs and inclusive development, making suggestions for further research, and addressing the methodological and theoretical implications of the findings. As regards the latter, we argue that an inclusive development lens provides more in-depth insights into to the inherent tensions and contradictions of a 'CSV business case approach' and into processes of inclusion, exclusion and adverse inclusion. These insights provide justification for current proposals for legislation mandating responsible business conduct and due diligence under discussion in countries like France, Germany, and the Netherlands (Bright, 2020; Buhmann, 2019; Rombouts, 2019; Seifert, 2020).

\section{CSV Through an Inclusive Development Lens}

This study employs an inclusive development lens to analyse how Nestlé operationalises and implements its CSV approach and to uncover the inherent tensions and trade-offs of this business model. Originating in international development studies, inclusive development theory problematizes trade-offs between economic growth and social or environmental sustainability and distinguishes social, relational and environmental dimensions of inclusivity (Gupta \& Pouw, 2017; Gupta \& Vegelin, 2016; Gupta et al. 2015; Hickey et al. 2015; Pouw \& Gupta, 2017; Ros-Tonen et al. 2019). Inclusive development theory does not provide a basis to operationalise the economic dimension as it rejects an a priori commitment to economic growth, arguing that the Anthropocene requires a prioritisation of social and environmental inclusiveness above economic growth and profit orientation (Gupta \& Vegelin, 2016; Gupta et al. 2015; Pouw \& Gupta, 2017). As such, it is at odds with the CSV approach, which builds on the triple bottom line to balance profitability aims with social and environmental goals (Elkington, 1998). Instead, it adds a normative and critical—but 


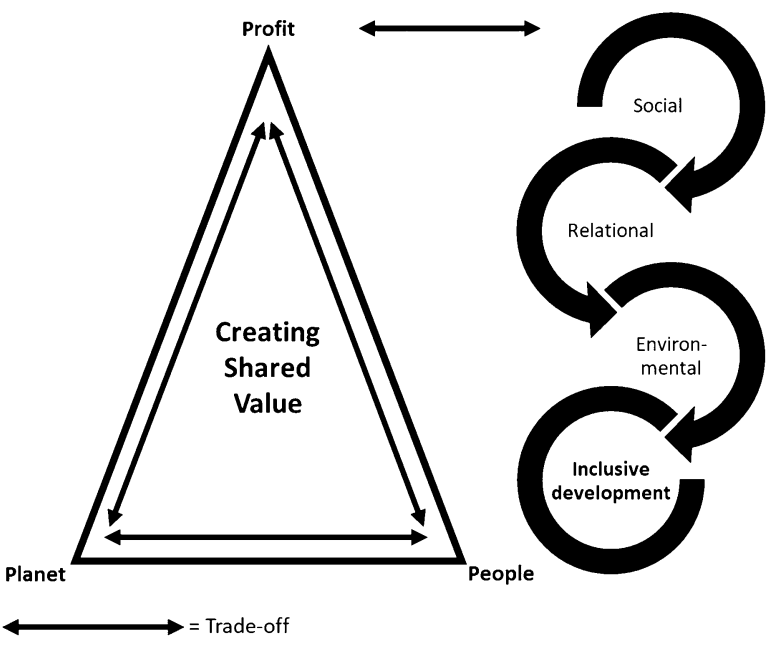

Fig. 1 Conceptual framework to analyse a company's application of the CSV approach from an inclusive development perspective, showing the trade-offs between planet, people and profit within the CSV approach, the three intrinsically related dimensions of inclusive development, and the inherent tension between the two approaches based on profit and growth orientation

constructive - perspective to the business model approach that dominates CSV literature.

The social dimension of inclusive development includes a concern for the material, psychological and cognitive-subjective aspects of producers' wellbeing (Gupta et al. 2015; Ros-Tonen et al. 2019) and alignment with their realities in terms of aspirations, opportunities, constraints and vulnerabilities (Ros-Tonen et al. 2019). The relational dimension encompasses an empowerment and gender perspective. The first focuses on tackling inequalities and power differences and enhancing the capacity of the poor and marginalised to exert choice (take control over their own life) and voice (demand equitable rights and fair conditions of value chain engagement) (Hicky et al., 2015; Gupta et al., 2015; Eerdewijk et al., 2017). The gender perspective specifically recognises the gendered risks and opportunities of value chain integration and their intersectionality with age, race, ethnicity, religion and location (Eerdewijk et al. 2017; Hickey et al. 2015; Quisumbing et al. 2015; Stoian et al. 2018). The environmental dimension is conceptualised as the commitment to avoiding or mitigating negative environmental impacts (Gupta \& Vegelin, 2016; Likoko \& Kini, 2017). Although these three dimensions of inclusive development remain rather general, they provide useful guidance for deconstructing the way in which companies operationalise shared value creation in their discourses and practices, while making the more normative positions that underpin the analysis explicit (Ros-Tonen et al. 2019). It should be noted that this conceptualisation of inclusive development refers to processes rather than outcomes of the relation between companies and producers (Ibid.). Together, the three dimensions of inclusive development help explain the constraints regarding the scope and impact of CSV strategies. We thereby primarily focus on the tension between a company's profit orientation and the shared (social and environmental) value that it aims to create (Fig. 1).

\section{Methodology}

\section{Unit of Analysis}

This study aims to deconstruct the CSV approach - and in particular its understanding of 'societal value' - from an inclusive development perspective by presenting an exploratory study of a 'typical case' (Gerring, 2008). It focuses on Nestlé-a fast-moving consumer goods company that explicitly incorporates the CSV discourse in its business strategy and cocoa supply chains and was an important source of inspiration to Porter and Kramer (2011).

\section{Data Collection}

The research took place in the Netherlands (August-September 2017; March-May 2018) and Ghana (October-December 2017). We triangulated data from different sources to facilitate a broad understanding of corporate discourses and practices, while reducing the risk of bias caused by using only one data collection method (Bowen, 2009; Sharp, 2006). The document sample consisted of 19 corporate documents and web communications, including the company's annual financial and CSV reports, and two public interviews. The sample can be considered representative of Nestlé's discourse and reporting, as it includes the most relevant reports the company published since it started its cocoa value chain programme in 2009.

A total of 28 semi-structured interviews were held. These respondents were purposively selected based on their involvement in the company's CSV strategy and cocoa supply chain programme and identified through snowball sampling. They included staff involved in the design and/or implementation of the strategy $(n=3$ in Europe, and $n=3$ in Ghana; category A); partners within the value chain (e.g. other companies, sector-wide organisations and NGOs) $(\mathrm{n}=13$, all but one in Ghana; category B); and stakeholders outside the value chain (e.g. government bodies and advocacy groups) ( $n=6$ in the Netherlands, $n=3$ in Ghana; category $\mathrm{C}$ ). In the results sections we refer to the interview number and respective categories where relevant (e.g. Interview A1). Staff directly involved in the implementation of Nestlé's CSV strategy were approached by e-mail to schedule an appointment. Most interviews $(n=23)$ were held faceto-face, and five interviews via phone or videoconferencing 
software. Although a small number of important stakeholders, such as the Ghana Cocoa Board (COCOBOD), were unwilling to grant an interview, overall a good coverage and level of access to key actors in each of the three respondent categories was attained, as evidenced by the saturation level of data and information gathered (Bryman, 2012). The case study company and its suppliers were relatively open to participate in the research. The interviews, which lasted for about 1 hour and 15 minutes on average, were conducted using a general topic list, which focused on the respondents' experience with the CSV approach, Nestlé's Cocoa Plan and specific issues in the cocoa sector. The interview guides have been added as supplementary material (Annex 1). Nineteen interviews were recorded and extensive notes were taken during the other interviews, depending on the situation and the interviewee's comfort with being recorded. The recordings or notes were used to write transcripts or extensive summaries of the interviews, which also included notes about the general context, first impressions, and remarkable moments during the interview. It was agreed with the respondents that no literal quotes from the interviews would be published, in order to encourage information-sharing and guarantee their anonymity.

Five cocoa farmer communities involved in the Nestlé Cocoa Plan and a cocoa depot in the Ashanti Region of Ghana were visited. Eight semi-structured focus groups with farmers (category D) were organised during these trips, comprising 8-25 participants each. Most visits were unannounced or only announced at short notice, resulting in a relatively unorganised sampling process of focus group participants. As a result, there was a relative overrepresentation of male farmers in more powerful positions (such as lead farmers or purchasing clerks). A general topic list (Annex 2 ) was used during the focus groups, while leaving ample room for issues to be brought up by the participants. Topics discussed included experiences with the cocoa-buying company in question, the Cocoa Plan, and related projects in their community. The focus groups were usually followed by open interviews with some of the focus group participants $(n=7$; Category E), often leaders of farmer groups ('lead farmers'), purchasing clerks or community members who were involved in projects, for example related to child labour or healthcare. Extensive notes were made during the focus groups and interviews, but no recordings, in order not to limit the freedom of the participants to express themselves. These notes were elaborated upon return from the field visits. Data collection in Ghana was facilitated by a research assistant, who assisted in contacting a number of interviewees and translated interviews and focus group discussions that were held in the local language (Twi).

Two of the five community visits were facilitated by employees of Nestlé's suppliers and included demonstrations of trainings and visits of farms or seedling nurseries.
These organised trips enabled observation of cocoa depots, farms, and projects that are part of the Cocoa Plan and the interactions between company staff and farmers, as well as informal conversations with company staff, as such allowing a better understanding of the companies' operations and practices. Although company staff influenced the selection of communities and the data collection process during these visits, we believe that their overall impact on the results was limited. First, it was still possible to have fairly open and indepth focus groups and interviews with the farmers. Second, the outcomes of the focus groups that were held during the organised visits did not differ strongly from the three independently organised visits. Third, the multi-method research design allowed to counteract a possible bias through triangulation with data from document analysis, semi-structured interviews, and literature.

\section{Data Analysis}

The companies' discourses and practices were analysed through a qualitative content analysis of corporate documents, semi-structured interviews, and focus groups and the outcomes compared and triangulated in order to develop balanced answers to the research questions (Hsieh \& Shannon, 2005; O'Leary, 2004). The data was coded using ATLAS.ti software, following an iterative approach which combined deductive (or concept-driven) coding based on theory, the analytical framework and operationalisation, and inductive (data-driven) topic coding to enable themes to emerge from the data. The initial coding list was rather general, based on the dimensions of inclusive development and definitions of the CSV discourse. This list was complemented by more specific codes that emerged during the coding process. These new codes related to specific issues in the cocoa sector, specific instruments applied, concrete outcomes, or general topics that emerged from the data (see Annex 3). After the coding process was completed, quote lists were generated for specific codes in order to link codes and themes to the theoretical framework (Saldaña, 2009). Numerical data in corporate reports (e.g. statistics about certified cocoa or the number of trained farmers) and fieldwork notes were organised in separate documents. Secondary sources, such as impact studies, were used to triangulate some of the outcomes, especially when the primary data was insufficient to reach sound conclusions.

\section{Quality Assessment}

Table 1 summarises how indicators of "good qualitative research" (O'Leary, 2004), such as subjectivity with transparency, dependability, authenticity, transferability and auditability, have been approached and met in this research. 
Table 1 Quality criteria for qualitative research (drawing from O'Leary, 2004)

\begin{tabular}{ll}
\hline Indicator & Assessment \\
\hline $\begin{array}{l}\text { Subjectivity with transparency } \\
\text { Dependability }\end{array}$ & $\begin{array}{l}\text { Subjective positioning (e.g. regarding using an inclusive development lens) has been made explicit } \\
\text { Muthenticity }\end{array}$ \\
$\begin{array}{c}\text { Limitations in understanding farmers' views, experiences, and practices due to limited number and dura- } \\
\text { tion of field visits, interviews, focus groups have been compensated through triangulation of methods } \\
\text { and sources } \\
\text { The analysis generates relevant lessons for other companies and government policies and helps to criti- } \\
\text { cally interrogate the relational and inclusivity dimensions of the CSV discourse } \\
\text { Transparency and discussion of the research methods allows others to see how conclusions were reached }\end{array}$ \\
Auditability
\end{tabular}

\section{The Ghanaian Cocoa Sector: Societal Issues and Corporate Responses}

Ghana is the second-largest producer of cocoa in the world, producing approximately one fifth of the global cocoa supply in the 2016/17 season (970,000 metric tonnes) (ICCO 2018). Most of the estimated 800,000 cocoa farmers are smallholders with farms of 1-3 ha and average yields of approximately $400 \mathrm{~kg} / \mathrm{ha}$ (Hütz-Adams et al. 2016). The Ghana Cocoa Board (COCOBOD), an independent government body, regulates the cocoa sector and is responsible for selling the country's cocoa production on the global market (Laven, 2010). Licensed Buying Companies (LBCs) buy the cocoa from farmers for a nationally determined price per bag via purchasing clerks and sell their supplies to COCOBOD for a fixed price.

The Ghanaian cocoa sector currently faces a wide range of societal issues, including farmer poverty, deforestation, and a weak position of farmers in supply chain governance (Fountain \& Hütz-Adams, 2015, 2018; Higonnet et al. 2017). Farmer poverty is one of the most pressing issues in the cocoa sectors of Ghana and Côte d'Ivoire. With current farmgate prices, farmer incomes generally remain (far) below living income ${ }^{2}$ estimates and the World Bank International Poverty Line (Balineau et al. 2017; Fountain \& Hütz-Adams, 2015; True Price \& Fairtrade International, 2018; True Price \& Sustainable Trade Initiative, 2016). Farmer poverty is also seen as a key driver of other issues, such as poor working conditions, gender inequity, and the occurrence of the worst and hazardous forms of child labour (Fountain \& Hütz-Adams, 2015; see International Labour Organization, 2018 for definitions). Most cocoa farmers in Ghana are unorganised and lack bargaining power vis-à-vis COCOBOD, cocoa-buying and -trading companies, as well

\footnotetext{
2 A living income is defined as net household income, earned under decent working conditions, sufficient to enable all household members to afford a decent standard of living, including the costs of essential needs such as food, healthcare, education, housing and savings for unexpected events or emergencies (Komives et al. 2015).
}

as in sustainability programmes and initiatives, and as such generally have limited influence on value chain governance (Laven, 2010). At a global level, farmers have little influence on the currently highly unequal distribution of value in the cocoa value chain and relatively low market prices for cocoa (Fountain \& Hütz-Adams, 2015). Environmental issues related to cocoa value chains include monoculture, deforestation and detrimental effects of (excessive) use of agrochemicals (Fountain \& Hütz-Adams, 2015). Cocoa and chocolate companies - including Nestlé - are also concerned about commercial challenges to their business operations and the long-term stability of their cocoa supplies due to climate change, ageing farmers, and diseased trees (Hütz-Adams et al. 2016) and about reputational damage as a result of advocacy campaigns against child labour, farmer poverty and carbon risks (Lee \& Vachon, 2016).

In response, most major chocolate and cocoa companies have set up sustainability programmes and certification schemes, such as UTZ, Rainforest Alliance and Fairtrade (Annex 4). In addition, companies have joined in sector-wide initiatives such as the World Cocoa Foundation's CocoaAction strategy, the Cocoa \& Forests Initiative, and the International Cocoa Initiative (ICI). Some major chocolate manufacturers (e.g. Mars, Ferrero, and Hershey) have set 100 percent 'sustainable cocoa' sourcing targets for 2020, while others have lower goals (e.g. Nestlé and Mondelēz) (HützAdams et al. 2016). However, there is no generally accepted definition of 'sustainable cocoa', and companies include both certified and non-certified cocoa in these commitments.

\section{Results}

\section{Creating Shared Value through the Cocoa Plan}

In cooperation with Porter and Kramer, Nestlé has developed an extensive narrative about CSV as a fundamental principle of its business strategy, through which it aims to create value for its shareholders as well as for the people in the countries in which it operates (Nestlé 2013a, 2016). It also considers CSV to be the way through which the company 
contributes to the Sustainable Development Goals (SDGs) (Nestlé, 2016, 2018). In its annual CSV reports (Nestlé, 2011, 2013a, 2015, 2016), the company has developed an extensive vision on its role in the rural development of the regions from which it sources commodities such as cocoa, coffee, milk, and palm oil. Nestlé explicitly aims to 'enhance livelihoods and develop thriving communities' in rural areas through shared value creation (Nestlé, 2017, p. 75).

Nestlé launched its cocoa supply chain sustainability programme, the Cocoa Plan, in 2009. By ensuring a longterm, stable supply of higher-quality cocoa and reducing the complexity of these supply chains (Nestlé, 2015, 2016), the Cocoa Plan is designed to deliver commercial value to the company by reducing (future) costs. Moreover, Nestlé intends to meet consumer preferences for more sustainable and traceable products through the Cocoa Plan (Lommen, 2017; Nestlé, 2008, 2013a, 2016) and as such to differentiate its products from those of its competitors, which should lead to higher sales and an improved reputation (Nestlé, 2017, 2018a). The Cocoa Plan is also a response to various challenges from media outlets and advocacy groups about issues in the cocoa sector, most notably child labour. It aims at improving the quality of the cocoa that is sourced, supply chain structures (the 'Better Cocoa' pillar), farming practices ('Better Farming'), and the livelihoods of farmers and their families and communities ('Better Lives') (Nestlé, 2015, 2016). In doing so, the Cocoa Plan aims to create societal value by improving the wellbeing of cocoa farmers and the communities in which they live.

Nestlé mainly implements the Cocoa Plan in its supply chains originating in Côte d'Ivoire and Ghana. In contracts with its suppliers the company agrees on paying a premium price for certified and traceable cocoa and a set of additional activities to be implemented in (some of) the communities from where cocoa is sourced (Nestlé, 2017; Interview A6). In 2019, the Cocoa Plan covered 44 percent $(183,000$ tonnes) of Nestlé's total cocoa uptake and reached approximately 11,000 farmers worldwide (Nestlé, 2020a). Nestlé did not meet its target to extend the Cocoa Plan and related CSV approach to about 55 percent of its total cocoa uptake by 2020 (230,000 tonnes), announcing instead that it intends to source $100 \%$ of its cocoa for confectionery (about 300,000 tonnes) through the Cocoa Plan by 2025 (Nestlé, 2020b).

In Ghana, Nestlé had implemented the programme through two cocoa-trading companies in 11 districts in the Ashanti and Eastern Regions by 2017. One of these companies has its own cocoa sourcing division in Ghana, while the other has contracted a Ghanaian cocoa-buying company (Licenced Buying Company (LBC) (Fig. 2). ${ }^{3}$

\footnotetext{
3 The names of the supplier companies are withheld for privacy reasons and power relations between the companies.
}

Nestlé invested approximately CHF 30 to 40 million (EUR 26-35 million) ${ }^{4}$ in the Cocoa Plan in 2016 and 2017, which equals 0.7 percent of the total sales value of Nestlé's chocolate products in 2017 (Table 3) (Nestlé 2018b). ${ }^{3}$ This includes costs for providing farmers with high-yielding, disease-resistant cocoa tree seedlings to replace ageing, less productive trees, inputs (such as pesticides and fertilisers), tools, and protective clothing that farmers should use when applying agrochemicals (Interviews A2, A3, A4, Focus groups D1-8). As part of the certification process, the cocoa-trading companies also support the formation of cooperatives and farmer groups and develop supply chain traceability systems that allow companies to trace the cocoa back to the farm from where it was sourced, and pay certification premiums to farmer groups and individual farmers. The average premium paid to Nestlés suppliers for the implementation of the certification and farmer training activities was CHF 154 (EUR 133) per tonne in 2016 and 2017 (calculation by the authors). This equals an additional expenditure of 6.8 percent of the average cocoa price in these years. Seventy percent of this premium is dedicated to the administrative costs for certification (such as the UTZ licensing fee), the costs and profit margins for the cocoatrading and cocoa-buying companies (including audits), and the farmer group premium, which is used to fund farmer trainings and other in-kind support (Table 2) (Interview A6). In Ghana, COCOBOD also takes a share of the additional price that is paid for certified cocoa (Interview A3). The remaining 30 percent of the amount Nestlé pays in addition to the cocoa price is spent on cash premiums for farmers, which in Ghana would equal an average premium of GHS 16 (EUR 3.22) $)^{5}$ per bag of cocoa $(64 \mathrm{~kg})$. The total costs of certification, farmer training, premiums for farmer groups and cooperatives, and cash premiums accounted for about three quarters of the programme's costs in 2017. Furthermore, the company on average spent CHF 5 million (EUR 4.3 million) on child labour and education projects.

\section{Creating Shared Value through an Inclusive Development Lens}

This section analyses the implementation of Nestlé's CSV approach in Ghana along the three dimensions of inclusive development and the indicators specific to inclusive value chains.

\footnotetext{
${ }^{4}$ Based on the average exchange rate for 2017 of 1 CHF (Swiss franc) $=0.8668$ euro (European Central Bank, 2018).

5 Based on the average exchange rate for 2017 of 1 GHS (Ghana cedi) $=0.2016$ EUR (European Central Bank 2018)
} 
Fig. 2 Simplified overview of the Cocoa Plan supply chain structure in Ghana

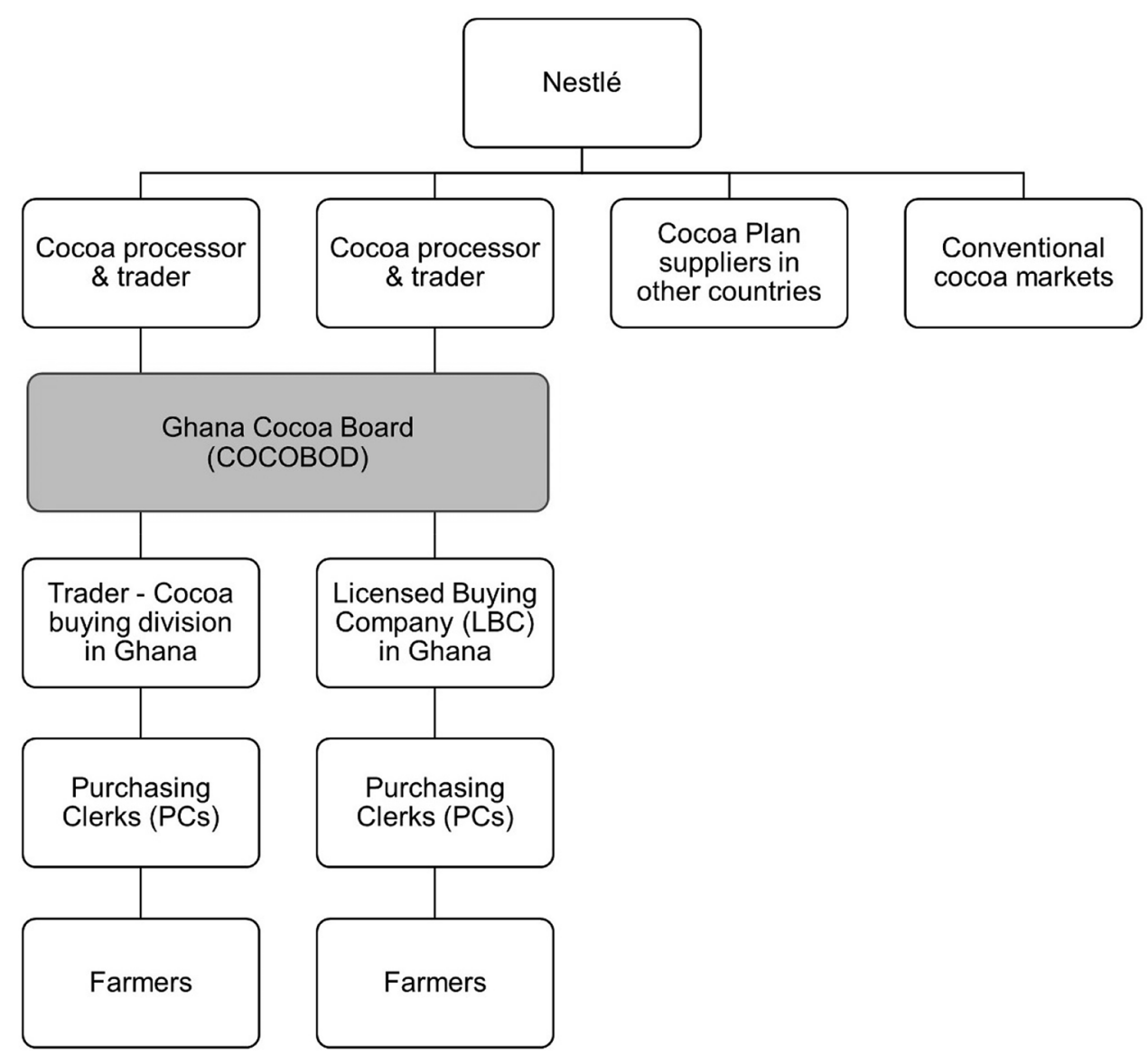

\section{The Social Dimension}

Concern for Wellbeing The Cocoa Plan aims to contribute directly to farmers' material wellbeing through the price premiums paid for UTZ-certified cocoa. These amounted to 12 , 17 or 18 GHS (2.42-3.64 Euro) in the communities visited in 2017, depending on the community and supplier (Focus groups: D1-5). The cash premium thus accounts for a sup-

Table 2 Cost overview of Cocoa Plan in 2016 and 2017 (Source: Nestlé 2017a, p. 88, 2018b)

\begin{tabular}{lll}
\hline Nestlé Cocoa Plan costs in thousands CHF & 2016 & 2017 \\
\hline $\begin{array}{l}\text { Cocoa research and development, and plant distri- } \\
\text { bution }\end{array}$ & 3,245 & 3,625 \\
Membership of organisations and global projects & 1,617 & 1,604 \\
Nestlé Cocoa Plan projects & 678 & 842 \\
CLMRS $^{\mathrm{b}}$ and school building & 5,516 & 4,482 \\
Farmer cash premium & 7,068 & 9,299 \\
$\begin{array}{l}\text { Co-op premium, certification, training and other } \\
\text { costs }\end{array}$ & 12,135 & 21,901 \\
Total & 30,259 & 41,753 \\
\hline
\end{tabular}

${ }^{\mathrm{a}} 1 \mathrm{CHF}=0.8668$ EUR (European Central Bank, 2018)

${ }^{\mathrm{b}}$ Child Labour Monitoring and Remediation System plement of 2.5-3.8 percent on top of the standard price per bag of 475 GHS (96 Euro) in the 2016/2017 and 2017/2018 seasons. However, certified farmers in most of the visited communities only received a premium for bags that they sold during the main harvest period-locally referred to as the 'bumper season'-which usually runs from October to December or January (Focus groups: D2-8; Interviews E2-5). Anecdotal evidence provided by individual farmers and purchasing clerks suggests that certified farmers only receive a cash premium for 30 to 50 percent of their annual cocoa production. The data is inconclusive as to the scale and reasons for this phenomenon.

It remains unclear to what extent Cocoa Plan activities that aim to increase farmer incomes (i.e. the UTZ certification scheme, training farmers, the cash premiums, and income diversification projects) lead to substantially increased farmer incomes (Interviews A3, A6, B2, B6, B11). A comprehensive impact study of UTZ certification programmes in Ghana did not find significant differences between certified and non-certified farmers in terms of increased productivity and incomes (Waarts et al. 2014). Some individual farmers had seen increased yields at their own farms because of the trainings and inputs. Yet overall, most farmer groups 
observed a decline in yields, which they mainly attributed to (local) climate change and a lack of financial resources. In addition, while farmers appreciated the cash certification premiums, they flagged the limited period ('bumper season') during which they would receive these as an important issue of concern. Interviewed employees and other actors who work with Nestlé attributed the declining yields also to the conservative attitudes of farmers towards adopting new practices, and a lack of financial resources to purchase inputs and tools (Interviews A3, A6, B2, B6, B11). Although Nestlé also implements income diversification projects in Ghana (e.g. soap making or farming palm weevil larvae as a source of income and protein), the scale at which these projects are implemented and their impact remain unclear.

In addition to efforts to increase farmers' income, Nestlé also aimed to improve health and sanitation facilities and practices by funding the Ghana Sustainable Water, Sanitation and Hygiene project (Gha-WASH) by the Ghana Red Cross Society (Nestlé, 2016, 2018a). Although implemented in only part of the communities from where it sources cocoa, interviewees were generally positive about these measures (Focus groups: D3-8, Interviews: E7-8).

Tackling Child Labour The Cocoa Plan addresses child labour through the Child Labour Monitoring and Remediation System (CLMRS), which Nestlé developed together with the International Cocoa Initiative (ICI) (Nestlé, 2013, 2015). This system makes specific community members responsible for the long-term monitoring of children that are at risk of engaging in hazardous forms of child labour (Nestlé and ICI, 2017). The ICI and the cocoa-buying company in question use the data to take individual or community-wide measures to prevent cases of child labour, such as assisting in the construction or renovation of schools, the organisation of educational sessions for children and adults on improving children's health and wellbeing, and supplying school kits. Nestlé started implementing the CLMRS in Ghana in 2016, but coverage in 2019 was below the company's expectations: the system only includes 2,430 children in Ghana as compared to 78,580 in Côte d'Ivoire (Nestlé, 2019a, 2020a). Initial results suggest that Nestlé's child labour programme is relatively successful, approximately halving the number of children who are registered as being engaged in child labour (Nestlé and ICI, 2017). Advocacy groups have explicitly praised the company's efforts on this issue, citing them as a 'best practice' in the cocoa sector (Boles, 2018; Fountain \& Hütz-Adams, 2018). According to internal reports (Nestlé and ICI, 2017) and external assessments (e.g. Fair Labor Association, 2018), Nestlé's efforts to combat child labour had relatively positive results.

Alignment with Farmers' Realities Nestlé, as well as many other cocoa and chocolate companies, promote a vision of the 'agripreneur' or 'entrepreneurial farmer' (Nestlé, 2018c; Otache, 2017). Nestlé and its suppliers encourage Cocoa Plan farmers to approach 'farming as a business', which requires investments in tools and inputs, farm management skills, and a continuous view on opportunities to make farms more efficient and productive (Nestlé 2013a, 2015, 2016, 2018a). This clashes with farmers' aspirations and expectations regarding the cocoa-buying companies. Many farmers and purchasing clerks who participated in the focus groups and interviews have strong expectations regarding the cocoa-buying companies to provide them with inputs, tools, credits, and incentives, such as Wellington boots and cutlasses (Focus groups: D1-8). The cocoa-buying companies, in contrast, assert that farmers could buy products such as a cutlass of GHS 15-20 (EUR 3-4) themselves, for example by using the certification premium they receive (Interview A3). Farmers insist on receiving 'incentives' and see them as 'a sign of appreciation' from the company. Moreover, they argue that they have insufficient financial resources and access to credit to make bigger investments, such as spraying machines or protective equipment. They are reluctant to collectively use their premiums for such purchases, as some farmers receive more premiums than others and thus effectively would be paying more. Although these strong expectations of cocoa farmers to receive incentives and free inputs from companies merit more research, part of the explanation can be found in COCOBOD's long-standing policies to provide free or subsidised inputs and services to farmers (e.g. fertilisers and spraying teams) (Laven, 2010) and cultural expectations regarding reciprocity and gifts in trading relations (Lyon, 2000; Ros-Tonen \& Derkyi, 2018).

\section{The Relational Dimension}

Empowerment, Gender Equity and Responsiveness The main empowerment issue addressed in Nestlé's CSV strategy is related to gender. In its CSV reports (Nestlé, 2015, 2016), Nestlé commits to promoting gender empowerment in its cocoa value chain. It recognises women's role in planting cocoa seedlings, harvesting and post-harvest activities (fermentation and drying), and the gender imbalances regarding access to land, tools, financial resources and cocoa revenues. From 2015, the company no longer develops a separate strategy for women, but opts to integrate gender awareness and training into its overall approach to sustainability (Nestlé, 2015). Its gender programme in the cocoa sector focuses primarily on Côte d'Ivoire, notably through gender awareness training for staff and cooperatives, collaborating with two women's associations on gender empowerment, and targeting women in literacy and livelihood diversification projects. 
Exerting Voice The second aspect of the relational dimension of inclusiveness that we analysed refers to the opportunities for farmers to exert voice and be represented (c.f. Hickey et al. 2015). Staff of Nestlé's suppliers and partner organisations indicated that the company is relatively open to feedback and suggestions (e.g. Interviews A2, A3, A6, B7). At the global level, Nestlé invites various advocacy groups to share their views on Nestlé's overall performance at annual stakeholder convenings, which are also attended by the company's CEO or chairman (Nestlé, 2013a, 2015, 2016, 2018a). However, cocoa farmers seem to be hardly involved in decision-making processes regarding the Cocoa Plan. Interviewed farmers indicated that they generally had little power to influence the cocoa-buying companies' decisions, let alone Nestlé's policies, on the activities implemented in their communities (Interviews B11, C2, C3, C7, C8, C9, E1-8; focus groups: D1-8). They further indicated that there is some room for them to be involved in the decisions on the content of the 'Community Action Plans' that are set up as part of the child labour projects in the Cocoa Plan and which include issues such as the construction or renovation of schools or teacher accommodation or sanitation facilities (Focus groups: D3-8, Interviews E3-7).

Clashing expectations and views of farmers and cocoabuying companies seem to considerably limit farmers' experience of 'shared value creation' between cocoabuying companies and themselves (Focus groups: D1-8). Their empowerment is limited by barriers they experience in communicating concerns to the cocoa-buying company with which they work. In some communities, the farmers are aware that they participate in Nestlé's supply chain and sustainability programme, but there is no direct communication or governance relation between the company and the farmers who take part in the Cocoa Plan.

\section{The Environmental Dimension}

The environmental dimension of the Cocoa Plan was operationalised poorly until 2019 , hence its limited effects on biodiversity loss and deforestation. There are significant tensions between increasing farmer productivity by (amongst other means) applying agrochemicals and the impact thereof on biodiversity and farmers' health. Although Cocoa Plan farmers are trained to apply 'Good Environmental Practices' as part of the UTZ certification scheme, several interviewees raised farmers' low adoption of these practices and their excessive use and unsafe storage of pesticides as issues of concern, which may cause strong negative effects on farmers' personal health and the environment (e.g. pollution of water bodies, biodiversity reduction) (Interviews A3, B11, C5, C7, C8). Several of the most commonly used pesticides in Ghana, including those that have been approved by COCOBOD and UTZ, are considered as 'highly hazardous' due to their toxic effects on biodiversity (such as bees), water bodies, and farmers' health (Pesticide Action Network UK 2018).

Cocoa production has had a long-term negative impact on deforestation in West-Africa (Higonnet et al. 2017). More specifically, tree-cover loss rates amounted to 10-19 percent between 2001 and 2017 in several districts in the Ashanti Region where Nestlé implements the Cocoa Plan (Global Forest Watch, 2018). Yet, the company started addressing the deforestation issue in its cocoa supply chains only from 2019. It prioritised other issues in the Cocoa Plan (notably child labour and farming practices) and chose to address deforestation in other value chains (soy and oil palm) (Nestlé, 2013b). More recently, Nestlé committed to the Cocoa \& Forests Initiative in 2017 and launched an action plan to end deforestation and restore forests in its cocoa supply chains in Ghana and Côte d'Ivoire in 2019 (Nestlé, 2019b). In Ghana, farm mapping and risk assessment have started, providing insights into encroachment of cocoa farms in forest reserves and national parks, and multipurpose trees have been distributed to stimulate agroforestry. Community-based forest protection and restoration activities were planned to start in 2020 (Nestlé, 2020c).

\section{Trade-offs}

In this section we review trade-offs-defined as a tension between two fields, resulting in gains in one objective at the cost of losses in another objective (Haffar \& Searcy, 2017; Hahn et al. 2010)—from the company's perspective. In the discussion we relate this to the broader literature.

The main trade-off experienced by the company concerns the alleged win-win outcome of CSV strategies in terms of private value (profitability) and societal value. According to the shared value logic, the increased costs of cocoa supplies (i.e. the 7 percent premium to the purchase price per tonne of cocoa sourced under the Cocoa Plan) should in some way financially benefit Nestlé, if the company's profit margins are to remain at least equal (Interview A5). Yet the commercial benefits of the programme, be it in terms of reduced cost, higher sales and revenues, or improved reputation, do not compensate for the overall costs of the Cocoa Plan.

In terms of cost, Nestlé has repeatedly indicated that the long-term financial feasibility of its work on child labour is problematic and that it has been looking to improve 'the cost effectiveness' of the system (Nestlé, 2015, 2016; Nestlé and ICI, 2017). This suggests that the Cocoa Plan does not provide a sufficiently convincing business case (defined as 'enlightened self-interest', see Schaltegger et al. 2012) to justify further investments in the programme's budget (Interviews $\mathrm{A} 1, \mathrm{~A} 6)$.

The Cocoa Plan does not lead to a win-win situation regarding the sales side either (Interview A5). Although 
consumer surveys about chocolate consumption generally show that consumers attribute high importance to the sustainability policies of chocolate manufacturers, this attitude does not translate clearly to their actual purchasing choices (Lommen, 2017). Market research in the Netherlands, commissioned by Nestlé, shows that the primary factors influencing a consumer's purchase decision are the chocolate product's flavour, type, and price, with sustainability being only one of the least important factors (Lommen, 2017). Demand for 'sustainable products' is stronger in Western Europe and North America than in Eastern Europe or Asia. Nestlé therefore chooses to use 100 percent certified cocoa only in certain markets, such as the Netherlands, the United Kingdom and Ireland (Nestlé Chocolade, 2017; Nestlé UK, 2015). The lack of consumer demand limits the business case for Nestlé to extend its sustainability programme to its full cocoa uptake (Interviews A5, A6). It also leads to tensions between different divisions and country offices within the company, for instance about the budget that is dedicated to the Cocoa Plan (Interview A5). Hence tensions remain between the company's profit maximisation goals and investments in the Cocoa Plan (Interview A6). This tension has become particularly salient since the introduction of a new profit maximisation strategy in 2017, which includes a CHF 2.5 billion (EUR 2.2 million) cost-cutting target (Gretler, 2018; Gretler \& Mulier, 2017). The plan was developed in response to strong pressure from the activist hedge fund Third Point and other shareholders to increase profits and growth rates (Bradshaw, 2017; Deveau, 2018).

A trade-off which negatively impacts the certification element of the Cocoa Plan (Interview A6) is the current oversupply of UTZ-certified cocoa on the global market (UTZ, 2018), which has led to declining market prices for certified cocoa by 40 to 50 percent since 2013. This increased the risks for farmers and cocoa-buying and -trading companies to invest in certification, as they might not be able to receive a profitable certification premium or even any premium at all (Interview A6). It furthermore increases the pressure on cocoa-trading and cocoa-buying companies to implement certification programmes as cost-efficiently as possible (Interview A3). Interviewed company staff and partners involved in the implementation of Cocoa Plan raised their concerns about cutting back excessively on farmer training budgets, which may result in fewer field officers and trainings for farmers and inflated numbers of certified farmers and bags of cocoa (Interviews A6, B6, B11).

Finally, Nestlé faces a reputation trade-off that Morsing et al. (2008) call the 'paradox of CSR communication': increased transparency about hazardous child labour and the challenges the company faces in this regard led to increasing visibility, increasing consumers' negative attitudes towards the company and resulting in negative press coverage. ${ }^{6}$ To limit reputational damage, the company actively tries to change these perceptions by giving interviews (Van Gelder, 2018) and organising press visits to Cocoa Plan communities (Dobber, 2016), but this has so far not resulted in changing attitudes from consumers (Interview A5).

\section{Discussion}

The findings show that Nestlé's CSV programme in Ghana's cocoa sector targets various dimensions of inclusive development, most notably the social dimension and, more recently, the environmental dimension. While Nestlé's Cocoa Plan intends to simultaneously generate private and societal value (e.g. by improving farmer wellbeing while also improving its reputation among customers and the stability of its cocoa supply), in practice the plan largely fails to overcome several persistent trade-offs (Table 3) (Crane et al. 2014; Van der Byl \& Slawinski, 2015).

Such trade-offs are not specific for Nestlé and have been documented more broadly in the literature on corporate sustainability (Haffar \& Searcy, 2017; T. Hahn et al. 2010; Van der Byl \& Slawinski, 2015) and creating shared value (Crane et al. 2014; Voltan et al. 2017). This literature makes clear that trade-offs occur at different levels and time scales and encompass different dimensions and tensions (Haffar \& Searcy, 2017; T. Hahn et al. 2010). This equally applies to Nestlé, which experienced trade-offs at the individual level (e.g. staff facing limitations regarding training or coverage of the CLMRS), organisational level (e.g. between different divisions and country offices about the budget allocated to the Cocoa Plan), and the industry as a whole (e.g. whether to commit fully to industry-wide alliances against child labour or against deforestation) (T. Hahn et al. 2010). Similarly, trade-offs exist in terms of performance (e.g. the costs of mitigating child labour - social performance - versus financial performance); stakeholders (e.g. consumers demanding sustainable products versus shareholders demanding higher profitability); process (different strategies to achieve CSV); outcomes (e.g. productivity increase versus adverse environmental effects of agrochemical use); measurement (e.g. transparency about child labour versus increased visibility of non-achievement and associated reputational damage); and time (e.g. between current profitability aims and the need

\footnotetext{
${ }^{6}$ Examples include articles with headlines such as 'Nestle 'failing' on child labour abuse, says FLA report' (Hawksley 2012) and 'Child labour on Nestlé farms: chocolate giant's problems continue' (Sandler Clarke, 2015), which appeared on the BBC and Guardian websites respectively.
} 


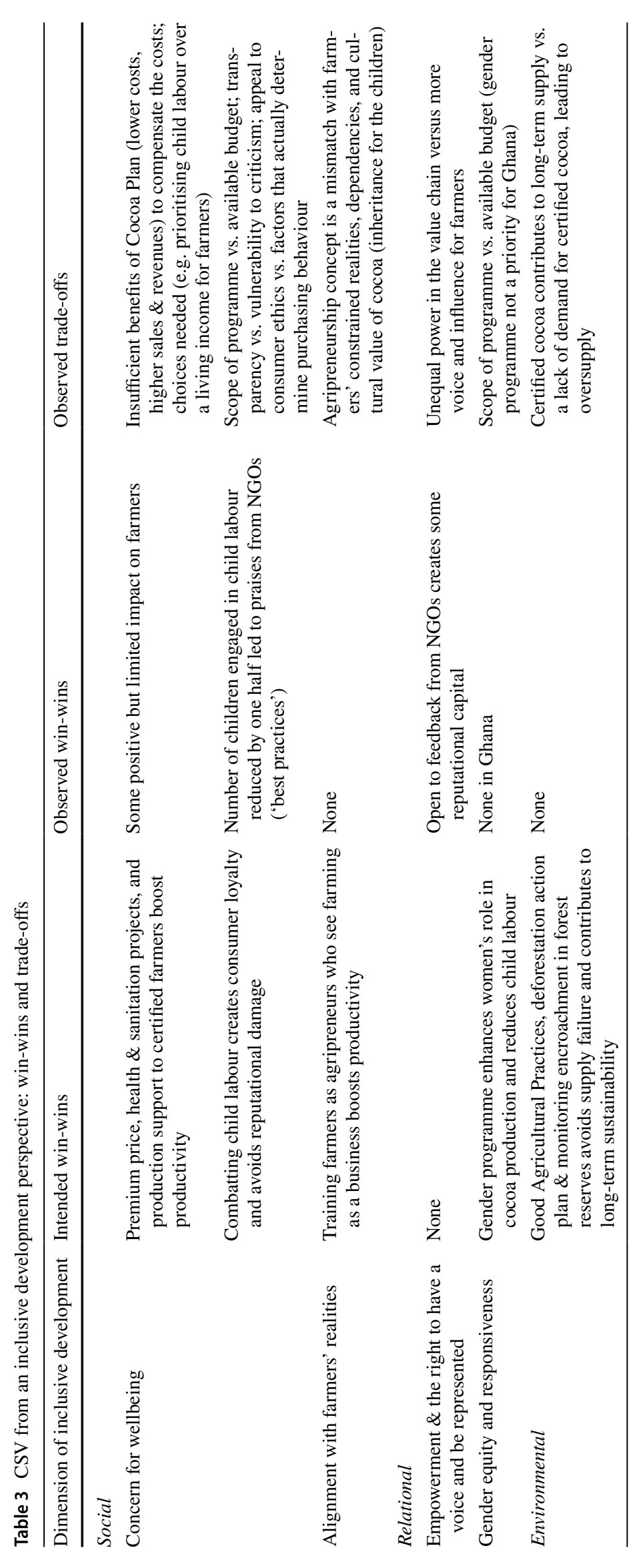


to secure future cocoa supplies) (Haffar \& Searcy, 2017; T. Hahn et al. 2010).

Recent business and management literature argues that such trade-offs should not be neglected, as in the 'win-win' and 'business case' narrative of CSV. Instead, there is growing advocacy for adopting a 'paradox perspective' in business strategies, which embraces such tensions (T. Hahn et al. 2018; Van der Byl \& Slawinski, 2015). A paradox perspective acknowledges and accepts trade-offs and "works through' them. This implies a shift from "either/or" to "both/ and" thinking (Nasim \& Sushil, 2011; Van der Byl \& Slawinski, 2015), suggesting that trade-offs can be overcome (T. Hahn et al. 2018, p. 237) - a perspective that is also prominent in a recent book by Freeman et al. (2020).

Inclusive development theory takes a different stand in this discussion. It argues that trade-offs are inherent in sustainability thinking and that the commitment to economic growth (inevitably) leads to strong trade-offs-usually in favour of economic growth (Gupta \& Vegelin, 2016; Gupta et al. 2015; Hickey et al. 2015; Ros-Tonen et al. 2019). It therefore foregrounds the social and environmental dimensions, while replacing the economic dimension with a relational one (Gupta \& Vegelin, 2016; Gupta et al. 2015). The latter encompasses voice and empowerment, and challenges discourses that perpetuate inequality and marginalisation of, for instance, low-income smallholders and women. Adding such an inclusivity lens to the analysis makes a methodological and a twofold theoretical contribution to debates on corporate sustainability and responsible business conduct.

Methodologically, inclusive development theory contributes to a better operationalisation of 'societal value'. It does so by distinguishing between social, relational, and environmental dimensions of inclusiveness (Gupta et al. 2015) and further operationalising this for smallholders-such as cocoa farmers-operating in global value chains (see Ros-Tonen et al. 2019). Applying this operationalisation, as we did in this paper, helps making tensions and contradictions explicit (Table 3). As such it can help companies to make informed choices regarding trade-offs (Ibid.).

Theoretically, inclusive development theory explains why the scope of CSV tends to remain limited. The analysis in this paper showed that the tension between creating private and societal value forced Nestlé to limit its CSV strategy to specific countries (e.g. tackling child labour and women empowerment particularly in Côte d'Ivoire, but less in Ghana), issues (e.g. prioritising child labour over deforestation), and markets (e.g. $100 \%$ certified cocoa for Dutch and UK markets only). One could argue that prioritising goals across countries, issues and markets or phasing them is an example of creatively working around tradeoffs between long-term sustainability goals and short-term profit targets. However, by emphasising the 'business case' for CSV, Nestlé's discourse does not reflect such a paradox perspective. This is seen in the tensions and constraints that staff experienced between simultaneously serving shareholders and stakeholders. It led to Nestlé's Cocoa Plan in Ghana performing relatively strongly on the social dimension of inclusive development (combatting child labour), while leaving other dimensions and issues, such as excessive use of agrochemicals and (until recently) deforestation, largely unaddressed.

Second, inclusive development theory adds a relational dimension to the analysis of business conduct. This sheds light on who has a say in the design and implementation of a company's sustainability and human rights strategy; if and how this leads to inclusion, exclusion or adverse inclusion; and whether this leads to the empowerment or disempowerment of marginalised groups. This extends the social dimensions to questions such as 'who is included and on what terms'. The findings show that farmers felt they had no influence on how Nestlé shaped and implemented its CSV strategy, but according to inclusive development theory, there can be no such thing as inclusion without influence. ${ }^{7}$ The relational dimension of inclusive development theory makes clear that the breadth and scope of Nestlé's Cocoa Plan is limited to dimensions of inclusive development that do not threaten the company's position in the value chain (e.g. child labour and deforestation), while leaving power imbalances and other relational dimensions unaddressed (e.g. gender empowerment and having a voice in the design of the company's CSV strategy). This bears the risk of 'adverse incorporation' of smallholders, with negative effects on particularly women and other marginalised groups (Hickey \& du Toit, 2013; Hickey et al. 2015).

This implies that CSV is at odds with the three dimensions of inclusivity (see Fig. 1), as shareholders will hold companies to account when their financial performance is at stake. When that happens, there is no 'business case' for CSV, as shown in this paper and argued elsewhere (e.g. De los Reyes \& Scholz, 2019). Although inclusivity drivers are hard to internalise via law, mandating companies to responsible business conduct and due diligence via legislation may level the playing field for companies now experiencing competitive disadvantages vis-à-vis those that choose not to make investments in addressing inclusivity issues in their value chains. This may contribute to converting responsible business conduct into a precompetitive condition for doing business, rather than an element of a company's business model that depends on the feasibility of business case solutions, as promoted by the CSV approach. Based on the due diligence process prescribed by the OECD Guidelines for Multinational Enterprises, such legislation gives clear guidance for companies as to how to systematically and

\footnotetext{
7 Thanks to an anonymous reviewer for pointing us to that direction.
} 
comprehensively approach inclusivity issues in their value chains, rather than CSV's tendency to address issues based on the feasibility of a business case. Such legislation has been adopted in certain countries and for certain sectors or issues (e.g. the US Dodd-Frank Act (Section 1502), the EU Conflict Minerals Regulation, the French law on the Devoir de Vigilance, the Dutch Child Labour Due Diligence Law) and is currently under discussion in e.g. Germany, the Netherlands and at the EU level (Bright, 2020; Buhmann, 2019; Rombouts, 2019; Seifert, 2020).

Further research is needed to explore whether the three inclusivity dimensions are better served by business models based on other drivers, such as social enterprises. Further research may also expand the inclusivity framework to a broader sample than a single case study such as this to uncover win-wins and trade-offs and the choices made in this regard. The inclusivity framework can further be used to assess the role of governments and other actors in shared value creation processes. Depending on the research objective, more specific operationalisations, for example with a focus on environmental impacts (Bolwig et al. 2010), capabilities (Renouard \& Ezvan, 2018), power relations (Gradin, 2016) or human rights (R. Hahn, 2012) could also be used.

\section{Conclusion}

Although a CSV approach is likely to be more successful in integrating societal concerns into business models than more conventional business approaches, a 'reinvention of capitalism' it is certainly not. Based on an analysis of Nestlé's CSV strategy through an inclusive development lens, we found that the CSV logic finds itself entangled in the 'Porter Paradox' (Blowfield \& Dolan, 2014). This implies that CSV does not manage to overcome the tension between mitigating negative impacts on society or the environment and improving a company's competitive advantage by cutting and externalising costs. Despite recent calls to embrace and overcome such trade-offs through paradox, integrative or responsible business approaches (Van der Byl \& Slawinski, 2015), the findings of this study confirm that there are fundamental tensions between creating private and societal value that are not easy to overcome, while a CSV logic fails to address the relational dimension of inclusive development that emphasises empowerment and ensuring representation. Although redefining certain issues as shared value opportunities delivered positive results in some respects, this study showed that, in a still largely short-term-oriented, competitive business environment, a company reduces rather than enhances its competitiveness by integrating 'external costs' in its business operations. Based on this case, we cannot conclude that there is a clear, commercially profitable 'business case' for large multinational enterprises to address value chain inclusiveness issues such as deforestation or child labour at scale. To the contrary; thinking in terms of a business case creates an incentive for companies to reduce the costs and scope (and thereby the impact) of 'societal value creation'. As long as financial value maximisation continues to be the ultimate performance indicator by which a company is held to account by its shareholders, tensions between tackling inclusivity issues and commercial objectives remain. Although it is hard to conclude on the basis of a single case study that the CSV approach is ineffective by definition, the inclusive development perspective at least shows the problematic nature of combining private and societal value as a pathway towards transformative change. Despite recent calls to embrace such tensions and deal with them creatively, from an inclusive development perspective such tensions are inherent in a growth- and profit-oriented economy. Recent proposals to mandate responsible business conduct and due diligence through legislation may contribute to reducing this tension.

Supplementary Information The online version contains supplementary material available at https://doi.org/10.1007/s10551-021-04808-1.

\section{Declarations}

Conflict of interest The authors declare that they have no conflict of interest. Nestlé and its partner companies were by no means involved in the design, data analysis or financing of the research.

Ethical Approval All procedures performed in studies involving human participants were in accordance with the ethical standards of the institutional and/or national research committee and with the 1964 Helsinki declaration and its later amendments or comparable ethical standards.

Informed Consent Informed consent was obtained from all individual participants included in the study.

Open Access This article is licensed under a Creative Commons Attribution 4.0 International License, which permits use, sharing, adaptation, distribution and reproduction in any medium or format, as long as you give appropriate credit to the original author(s) and the source, provide a link to the Creative Commons licence, and indicate if changes were made. The images or other third party material in this article are included in the article's Creative Commons licence, unless indicated otherwise in a credit line to the material. If material is not included in the article's Creative Commons licence and your intended use is not permitted by statutory regulation or exceeds the permitted use, you will need to obtain permission directly from the copyright holder. To view a copy of this licence, visit http://creativecommons.org/licenses/by/4.0/.

\section{References}

Aakhus, M., \& Bzdak, M. (2012). Revisiting the role of "shared value" in the business-society relationship. Business and Professional Ethics Journal, 31(2), 231-246. https://doi.org/10.5840/bpej2 01231211 
Balineau, G., Bernath, S., \& Pahuatini, V. (2017). Cocoa farmers' agricultural practices and livelihoods in Côte d'Ivoire. Notes Techniques (Vol. 24). Paris: Agence Française de Développement.

Banks, G., Scheyvens, R., McLennan, S., \& Bebbington, A. (2016). Conceptualising corporate community development. Third World Quarterly, 37(2), 245-263. https://doi.org/10.1080/01436597. 2015.1111135

Beschorner, T. (2013). Creating shared value : The one-trick pony approach-A comment on Michael Porter and Mark Kramer. Business Ethics Journal Review, 1(17), 106-112

Biswas, A. K., Tortajada, C., Biswas-Tortajada, A., Joshi, Y. K., \& Gupta, A. (2014). Creating shared value: Impacts of Nestlé in Moga, India. Springer. https://doi.org/10.1007/ 978-3-319-01463-0.

Blowfield, M., \& Dolan, C. S. (2014). Business as a development agent: Evidence of possibility and improbability. Third World Quarterly, 35(1), 22-42. https://doi.org/10.1080/01436597.2013. 868982

Boles, H. (2018). A matter of taste: A benchmark of current industry efforts to address child labour, worst forms of child labour and human trafficking on cocoa farms in Côte d'Ivoire and Ghana. Stop the Traffik Australian Coalition.

Bolwig, S., Ponte, S., Toit, A., Riisgaard, L., \& Halberg, N. (2010). Integrating poverty and environmental concerns into valuechain analysis. A conceptual framework. Development Policy Review, 28(2), 173-194. https://doi.org/10.1111/j.1467-7679. 2010.00480.x

Bowen, G. A. (2009). Document analysis as a qualitative research method. Quality Research Journal, 9(2), 27-40. https://doi. org/10.1002/bse.674.

Bradshaw, J. (2017, February 16). Nestlé's new boss sets out recipe for growth as sales disappoint. The Telegraph.

Bright, C. (2020). Creating a legislative level-playing field in business and human rights at the European Level: Is the French law on the duty of vigilance the way forward? EUI Working Paper MWP 2020/01. https://doi.org/10.2139/ssrn.3262787

Bryman, A. (2012). Social research methods. (4th ed.). OUP.

Buhmann, K. (2019). Business, human rights, and reflexive regulation: Multi-stakeholder development of standards for responsible business conduct. In: J. D. Rendtorff (Ed.), Handbook of business legitimacy. Responsibility, ethics and society (pp. 1-15). Berlin: Springer. https://doi.org/10.1007/978-3-31968845-9_1-1.

Christensen, L. T. (2007). The discourse of corporate social responsibility: Postmodern remarks. In S. May, G. Cheney, \& J. Roper (Eds.), The debate over corporate social responsibility. (pp. 448-458). OUP.

Corazza, L., Scagnelli, S. D., \& Mio, C. (2017). Simulacra and sustainability disclosure: Analysis of the interpretative models of creating shared Value. Corporate Social Responsibility and Environmental Management, 24(5), 414-434. https://doi.org/ 10.1002/csr.1417

Crane, A., Pallazo, G., Spence, L., \& Matten, D. (2014). Contesting the value of 'Creating Shared Value.' California Management Review, 56(2), 130-153. https://doi.org/10.1108/0960003941 0055963

De los Reyes, G., \& Scholz, M. (2019). The limits of the business case for sustainability: Don't count on 'Creating Shared Value' to extinguish corporate destruction. Journal of Cleaner Production, 221, 785-794. https://doi.org/10.1016/j.jclepro.2019.02.187.

De los Reyes, G., Scholz, M., \& Smith, N. C. (2017). Beyond the "WinWin." California Management Review, 59(2), 142-167. https:// doi.org/10.1177/0008125617695286.

Dembek, K., Singh, P., \& Bhakoo, V. (2016). Literature review of shared value: A theoretical concept or a management buzzword?
Journal of Business Ethics, 137(2), 231-267. https://doi.org/10. 1007/s10551-015-2554-z

Deveau, S. (2018, January 22). Loeb's third point calls for faster changes at nestle in letter. Bloomberg. Retrieved June 20, 2018, from https://www.bloomberg.com/news/articles/2018-01-22/ loeb-s-third-point-calls-for-faster-changes-at-nestle-in-letter.

Dobber, L. (2016, October 10). Hoe help je een cacaoboer? Trouw, pp. 2-3 (De Verdieping).

Eerdewijk, A. V., Newton, J., Tyszler, M., Wong, F., \& Vaast, C. (2017). A conceptual model of women and girls' empowerment. KIT. https://doi.org/10.1126/science.1258882.2

Elkington, J. (1998). Partnerships from cannibals with forks: The triple bottom line of 21 st-century business. Environmental Quality Management, 8(1), 37-51. https://doi.org/10.1002/tqem.33100 80106

European Central Bank. (2018). ECB euro reference exchange rate: Swiss franc (CHF). Retrieved June 20, 2018, from https://www. ecb.europa.eu/stats/policy_and_exchange_rates/euro_reference_ exchange_rates/html/eurofxref-graph-chf.en.html.

Fair Labor Association. (2018). Nestle. Retrieved June 21, 2018, from http://www.fairlabor.org/affiliate/nestle.

Fountain, A., \& Hütz-Adams, F. (2015). Cocoa barometer 2015. Tull en 't Waal: VOICE Network.

Fountain, A., \& Hütz-Adams, F. (2018). Cocoa barometer 2018. Tull en 't Waal: VOICE Network.

Freeman, R. E., Parmar, B. L., \& Martin, K. E. (2020). The power of AND: Responsible business without trade-offs. Columbia University Press.

Gerring, J. (2008). Case selection for case-study analysis: Qualitative and quantitative techniques. In J. Box-Steffensmeier, H. Brady, \& D. Collier (Eds.), The Oxford handbook of political methodology (pp. 645-684). OUP. https://doi.org/10.1093/oxfordhb/97801 99286546.003 .0028

Global Forest Watch. (2018). Interactive Map, Ghana, Ashanti. Retrieved June 20, 2018, from https://www.globalforestwatch. org/map/12/6.86/-1.93/GHA-1/grayscale/loss/607,556,580,592? tab $=$ analysis-tab\&begin $=2001-01-01 \&$ end $=2016-01-01 \&$ thres hold $=30$.

Gradin, S. (2016). Rethinking the notion of 'value' in global value chains analysis: A decolonial political economy perspective. Competition \& Change, 20(5), 353-367. https://doi.org/10.1177/ 1024529416657490

Gretler, C. (2018, February 15). Nestle CEO Schneider seeks deals as sales growth stutters. Bloomberg. Retrieved June 20, 2018, from https://www.bloomberg.com/news/articles/2018-02-15/ nestle-rules-out-raising-stake-in-l-oreal-opening-door-to-sale.

Gretler, C., \& Mulier, T. (2017, September 26). Nestle gives ground to billionaire Loeb, prioritizing profit. Bloomberg. Retrieved February 4, 2018, from https://www.bloomberg.com/news/artic les/2017-09-26/nestle-sets-profitability-target-as-schneider-detai ls-strategy.

Gupta, J., \& Pouw, N. (2017). Towards a trans-disciplinary conceptualization of inclusive development. Current Opinion in Environmental Sustainability, 24, 96-103. https://doi.org/10.1016/j. cosust.2017.03.004

Gupta, J., Pouw, N. R. M., \& Ros-Tonen, M. A. F. (2015). Towards an elaborated theory of inclusive development. European Journal of Development Research, 27(4), 541-559. https://doi.org/10. 1057/ejdr.2015.30

Gupta, J., \& Vegelin, C. (2016). Sustainable development goals and inclusive development. International Environmental Agreements: Politics, Law and Economics, 16(3), 433-448. https://doi.org/10. 1007/s10784-016-9323-Z

Haffar, M., \& Searcy, C. (2017). Classification of trade-offs encountered in the practice of corporate sustainability. Journal of 
Business Ethics, 140(3), 495-522. https://doi.org/10.1007/ s10551-015-2678-1

Hahn, R. (2012). Inclusive business, human rights and the dignity of the poor: A glance beyond economic impacts of adapted business models. Business Ethics: A European Review, 21(1), 47-63. https://doi.org/10.1111/j.1467-8608.2011.01640.x

Hahn, T., Figge, F., Pinkse, J., \& Preuss, L. (2010). Trade-offs in corporate sustainability: You can't have your cake and eat it. Business Strategy and the Environment, 19(4), 217-229. https://doi.org/ 10.1002/bse.674

Hahn, T., Figge, F., Pinkse, J., \& Preuss, L. (2018). A paradox perspective on corporate sustainability: Descriptive, instrumental, and normative aspects. Journal of Business Ethics, 148(2), 235-248. https://doi.org/10.1007/s10551-017-3587-2

Hawksley, H. (2012, June 29). Nestle 'failing' on child labour abuse, says FLA report. BBC News. Retrieved June 21, 2018, from https://www.bbc.com/news/world-africa-18644870.

Hickey, S., \& du Toit, A. (2013). Adverse incorporation, social exclusion, and chronic poverty. IDPM and University of the Western Cape. https://doi.org/10.1057/9781137316707_7

Hickey, S., Sen, K., \& Bukenya, B. (2015). The politics of inclusive development. Interrogating the evidence. OUP. https://doi. org/https://doi.org/10.1360/zd-2013-43-6-1064

Higonnet, E., Bellantonio, M., \& Hurowitz, G. (2017). Chocolate's dark secret. Mighty Earth.

Hsieh, H.-F., \& Shannon, S. E. (2005). Three approaches to qualitative content analysis. Qualitative Health Research, 15(9), 1277-1288

Hütz-Adams, F., Huber, C., Knoke, I., Morazán, P., \& Bonn, M. M. (2016). Strengthening the competitiveness of cocoa production and improving the income of cocoa producers in West and Central Africa. SÜDWIND e.V.

ICCO. (2018). Production of cocoa beans. ICCO Quarterly Bulletin of Cocoa Statistics, XLIV(2).

International Labour Organization. (2018). What is child labour. Retrieved August 2, 2018. from http://www.ilo.org/ipec/facts/ lang--en/index.htm.

Komives, K., Grunze, S., Krain, E., Tschanz, A., Daniels, S., \& Seville, D. (2015). Defining, calculating and using a living income benchmark in the context of agricultural commodities. ISEAL Alliance, GIZ, Sustainable Food Lab.

Laven, A. (2010). The risks of inclusion: Shifts in governance processes and upgrading opportunities for cocoa farmers in Ghana. KIT Publishers.

Lee, K.-H., \& Vachon, S. (2016). Business value and sustainability. Palgrave Macmillan UK. https://doi.org/10.1057/ 978-1-137-43576-7

Lenssen, G. G., \& Lenssen, J.-J. (2019). Managing sustainable business in a global context. In G. G. Lenssen \& N. G. Smith (Eds.), Managing Sustainable Business. An executive education case and textbook (pp. xiii-xxxviii). Springer.

Likoko, E., \& Kini, J. (2017). Inclusive business-A business approach to development. Current Opinion in Environmental Sustainability, 24, 84-88. https://doi.org/10.1016/j.cosust. 2017.03.001

Lommen, G. (2017). Albert Heijn nummer één, met huiswerk voor iedereen. FoodPersonality Juli/Augustus, 52-53.

Lyon, F. (2000). Trust, networks and norms: The creation of social capital in agricultural economies in Ghana. World Development, 28(4), 663-681. https://doi.org/10.1016/S0305-750X(99) 00146-1

Morsing, M., Schultz, M., \& Nielsen, K. U. (2008). The 'Catch 22' of communicating CSR: Findings from a Danish study. Journal of Marketing Communications, 14(2), 97-111. https://doi.org/10. 1080/13527260701856608

Nasim, S., \& Sushil. (2011). Revisiting organizational change: Exploring the paradox of managing continuity and change. Journal of
Change Management, 11(2), 185-206. https://doi.org/https://doi. org/10.1080/14697017.2010.538854.

Nestlé. (2008). Nestlé creating shared value report 2009. Nestlé S.A. Nestlé. (2011). Nestlé Creating Shared Value Update 2010. Nestlé S.A.

Nestlé. (2013a). Nestlé in society. Creating shared value and meeting our commitments 2012. Vevey: Nestlé S.A.

Nestlé. (2013b). Nestlé commitment on deforestation and forest stewardship. Nestlé S.A.

Nestlé. (2015). Nestlé in society. Creating shared value and meeting our commitments 2014. Vevey: Nestlé S.A.

Nestlé. (2016). Nestlé in society. Creating shared value and meeting our commitments 2015. Vevey: Nestlé S.A.

Nestlé. (2017). Nestlé: strong foundation, clear path forward, bright future. Presentation at Nestlé Investor Seminar 2017. London: Nestlé S.A.

Nestlé. (2018a). Nestlé in society. Creating Shared Value and meeting our commitments 2017. Vevey: Nestlé S.A.

Nestlé. (2018b). Annual review 2017. Nestlé S.A.

Nestlé. (2018c). Cocoa. Retrieved July 6, 2017, from https://www.nestle.com/csv/raw-materials/nestle-cocoa-plan.

Nestlé. (2019a). Tackling child labour: 2019 report. Nestlé S.A.

Nestlé. (2019b). Cocoa \& Forests Initiative: Nestlé's initial action plan to end deforestation and promote forest restoration and protection in the cocoa supply chain. Nestlé S.A.

Nestlé. (2020a). Nestlé Cocoa Plan. https://www.nestle.com/csv/rawmaterials/nestle-cocoa-plan

Nestlé. (2020b). Creating sharing value progress report 2019. Nestlé S.A.

Nestlé. (2020c). Tackling deforestation. Progress report 2020. Vevey: Nestlé S.A.

Nestlé Chocolade. (2017, May 31). 100\% duurzaam ingekochte cacao. Retrieved August 4, 2018, from https://www.nestle-chocolade. nl/nestle-cocoa-plan/nieuws/100-duurzaam-ingekochte-cacao.

Nestlé, \& ICI. (2017). Tackling child labour: 2017 report. Nestlé S.A. $\&$ International Cocoa Initiative.

Nestlé UK. (2015, December 8). Nestle to source $100 \%$ certified sustainable cocoa. Retrieved August 4, 2018, from https://www. nestle.co.uk/media/pressreleases/100pc-sustainable-cocoa.

Nichols, M. (2011). Nestle head emphasizes profiting from doing good. Retrieved August 10, 2020, from https://www.reuters.com/artic le/philanthropy-corporate/nestle-head-emphasizes-profitingfrom-doing-good-idUSN2214666620110322.

O'Leary, Z. (2004). The essential guide to doing research. The essential guide to doing research. Sage.

Otache, I. (2017). Agripreneurship development: A strategy for revamping Nigeria's economy from recession. African Journal of Economic and Management Studies, 8(4), 474-483. https:// doi.org/10.1108/AJEMS-05-2017-0091

Pesticide Action Network UK. (2018). Pesticide use in Ghana's cocoa sector. UTZ.

Porter, M. E., \& Kramer, M. R. (2011). Creating shared value. How to reinvent capitalism - and unleash a wave of innovation and growth. Harvard Business Review, 89(1-2), 1-17. https://doi. org/10.1108/09600039410055963

Porter, M. E., Kramer, M. R., Herman, K., \& McAra, S. (2015). Nestlé's creating shared value strategy. Harvard Business School Case, 716-422, November 2015.

Pouw, N., \& Gupta, J. (2017). Inclusive development: A multi-disciplinary approach. Current Opinion in Environmental Sustainability, 24, 104-108. https://doi.org/10.1016/j.cosust.2016.11.013

Quisumbing, A. R., Rubin, D., Manfre, C., Waithanji, E., van den Bold, M., Olney, D., et al. (2015). Gender, assets, and market-oriented agriculture: Learning from high-value crop and livestock projects in Africa and Asia. Agriculture and Human Values, 32(4), 705-725. https://doi.org/10.1007/s10460-015-9587-x 
Renouard, C., \& Ezvan, C. (2018). Corporate social responsibility towards human development: A capabilities framework. Business Ethics: A European Review. https://doi.org/10.1111/beer.12181

Rombouts, B. (2019). Modern international corporate social responsibility instruments and the protection of fundamental labour standards: An introduction to the Dutch international responsible business conduct agreements. In S. Bellomo \& A. Preteroti (Eds.), Recent labour law issues: A multilevel perspective. (pp. 233-246). Giappichelli Editore.

Ros-Tonen, M. A. F., Bitzer, V., Laven, A., Ollivier de Leth, D., Van Leynseele, Y. P. B., \& Vos, A. (2019). Conceptualizing inclusiveness of smallholder value chain integration. Current Opinion in Environmental Sustainability, 41, 10-17

Ros-Tonen, M. A. F., \& Derkyi, M. (2018). Conflict or cooperation? Social capital as a power resource and conflict mitigation strategy in timber operations in Ghana's off-reserve forest areas. Ecology and Society, 23(3), 150. https://doi.org/10.5751/ ES-10408-230344

Saldaña, J. (2009). The coding manual for qualitative researchers. Sage.

Sandler Clarke, J. (2015, September 2). Child labour on Nestlé farms: Chocolate giant's problems continue. The Guardian. Retrieved 21 June, 2018, from https://www.theguardian.com/global-devel opment-professionals-network/2015/sep/02/child-labour-on-nestle-farms-chocolate-giants-problems-continue.

Schaltegger, S., Lüdeke-Freund, F., \& Hansen, E. G. (2012). Business cases for sustainability and the role of business model innovation: Developing a conceptual framework. International Journal of Innovation and Sustainable Development, 6(2), 95-119. https://doi.org/10.2139/ssrn.2010506

Scheyvens, R., Banks, G., \& Hughes, E. (2016). The private sector and the SDGs: The need to move beyond 'business as usual.' Sustainable Development, 24(6), 371-382. https://doi.org/10. $1002 / \mathrm{sd} .1623$

Schmitt, J., \& Renken, U. (2014). How to earn money by doing good. Journal of Corporate Citizenship, 2012(45), 79-103. https://doi. org/10.9774/gleaf.4700.2012.sp.00007
Seifert, A. (2020). Corporate social responsibility and protection of workers' human rights: The case of Germany. Lex Social: Revista de Derechos Sociales, 10(2), 253-270. https://doi.org/10.46661/ lexsocial.5071

Sharp, J. (2006). Corporate social responsibility and development: An anthropological perspective. Development Southern Africa, 23(2), 213-222. https://doi.org/10.1080/03768350600707892

Stoian, D., Donovan, J., Elias, M., \& Blare, T. (2018). Fit for purpose? A review of guides for gender-equitable value chain development. Development in Practice, 28(4), 494-509. https://doi.org/ 10.1080/09614524.2018.1447550

True Price, \& Fairtrade International. (2018). Cocoa farmer income. The household income of cocoa farmers in Côte d'Ivoire and strategies for improvement. True Price.

True Price, T., \& Sustainable Trade Initiative. (2016). The true price of cocoa from Ivory Coast. True Price.

UTZ. (2018). UTZ cocoa statistics report. UTZ.

Van der Byl, C. A., \& Slawinski, N. (2015). Embracing tensions in corporate sustainability: A review of research from win-qins and trade-offs to paradoxes and beyond. Organization and Environment, 28(1), 54-79. https://doi.org/10.1177/1086026615575047

Van Gelder, H. (2018, January 31). Kinderarbeid in cacao niet verdwenen. De Telegraaf, p. 23

Voltan, A., Hervieux, C., \& Mills, A. (2017). Examining the win-win proposition of shared value across contexts: Implications for future application. Business Ethics: An European Review, 26(4), 347-368. https://doi.org/10.1111/beer.12159

Waarts, Y., Ingram, V., Linderhof, V., Puister-Jansen, L., Van Rijn, F., \& Aryeetey, R. (2014). Impact of UTZ certification on cocoa producers in Ghana, 2011 to 2014. Wageningen.

Publisher's Note Springer Nature remains neutral with regard to jurisdictional claims in published maps and institutional affiliations. 